keuangan pusat dan daerah dalam kerangka Negara Kesatuan Republik Indonesia sampai dengan terbentuknya Undang-undang tentang pemerintahan daerah sebagaimana diamanatkan oleh pasal 18, 18A dan 18B UndangUndang Dasar Negara Republik Indonesia tahun 1945 yang dituangkan dalam Undang-undang Nomor 32 Tahun 2004 tentang Pemerintahan Daerah dan Undang-undang Nomor 33 Tahun 2004 tentang Perimbangan Keungan antara Pemerintah Pusat dan Pemerintah Daerah.

3. Ketetapan Majelis Permusyawaratan Rakyat Republik Indonesia Nomor III/MPR/2000 tentang Sumber hukum dan tata urutan peraturan perundangundangan yang dituangkan dalam Undang-undang Nomor 10 Tahun 2004 tentang Pembentukan Peraturan Perundang-undangan.

4. Ketetapan Majelis Permusyawaratan Rakyat Republik Indonesia Nomor VI/MPR/2000 tentang Pemisahan Tentara Nasional Indonesia dan Kepolisian Negara Republik Indonesia sampai terbentuknya undang-undang yang terkait yang dituangkan dalam Undang-Undang Nomor 34 Tahun 2004 tentang Tentara Nasional Indonesia.

Berkaitan dengan Pasal 4 Ketetapan MPR No. 1 Tahun 2003, terdapat 11 (sebelas) Ketetapan MPR yang merupakan pekerjaan rumah bagi DPR, meskipun ada beberapa diantaranya sudah dirubah menjadi undang-undang. Terdapat 7 Ketetapan MPR lagi yang menjadi tugas dari DPR untuk segera dijadikan sebagai undang-undang. Permasalahannya adalah, ketersediaan waktu DPR untuk segera merealisasikan 7 Ketetapan MPR. Banyaknya tugas dan pekerjaan yang diemban oleh DPR menjadi penghalang. Meskipun demikian, optimisme untuk segera diselesaikannya tugas DPR tersebut masih tetap terbuka lebar. Hal ini tergantung dari keinginan DPR dalam menyikapi dan melaksanakannya sebagai bentuk tanggungjawabnya.
Perubahan terhadap ketetapan MPR membawa konsekuensi yuridis terhadap pemberlakuan ketetapan MPR yang sekiranya masih diberlakukan dan belum mengalami perubahan. Ketetapan MPR ini masih saja mengikat sebelum diadakan yang baru. Dengan demikian dapat berimplikasi pada peraturan perundang-undangan yang lainnya. berbunyi :

Aturan Peralihan Pasal 1 yang

"Segala peraturan perundangundangan yang ada masih tetap berlaku selama belum diadakan yang baru menurut UndangUndang Dasar ini.

Kemudian dalam Aturan Peralihan Pasal II yang berbunyi :

"Semua lembaga Negara yang ada masih tetap berfungsi sepanjang untuk melaksanakan ketentuan Undang-Undang Dasar dan belum diadakan yang baru menurut Undang-Undang Dasar ini”.

Dengan demikian ketetapan MPR tersebut masih mengikat meskipun berdasarkan pada undangundang Nomor 10 Tahun 2004, kedudukan Ketatapan MPR tidak lagi terdapat dalam tata urutan peraturan perundang-undangan. Hal ini memberikan arti bahwa Tap MPR tersebut tidak lagi dapat dijadikan sebagai dasar. Dengan adanya perubahan keberadaan produk hukum ketetapan MPR ini maka sifat mempengaruhi ke bawah bagi peraturan perundang-undangan tidak berlaku lagi.

Dalam pada itu, beberapa konsideran yang terdapat UU sebagai pelaksanaan ketetapan MPR, menimbulkan persoalan. Hal ini disebabkan karena ketetapan MPR 
merupakan sumber hukum secara formal dari peraturan perundangundangan yang berada di bawahnya. Terhadap peraturan perundangundangan sebelum adanya perubahan terhadap ketetapan MPR No. 1 Tahun 2003. Sebuah peraturan perundangundangan yang kehadirannya mengikat secara publik, berasal atau bersumber dari peraturan perundang-undangan yang lebih tinggi. Dengan adanya perubahan terhadap ketetapan MPR ini berakibat terhadap cacatnya produk peraturan perundang-undangan yang mendasarkan pada ketetapan MPR.

Apabila hal ini menimbulkan perubahan terhadap legitimasi dari berlakunya peraturan perundangundangan yang ada maka perlu dilakukan perubahan terhadapnya. Secara prosedur ketatatanegaraan perubahan terhadapnya memakan waktu yang sangat panjang sekali. Besar dan banyaknya jumlah peraturan perundang-undangan yang harus dirubah baik pada tingkat pusat maupun pada tingkat daerah, maka kekuatan mengikat yang dimiliki oleh peraturan perundang-undangan yang dibuat dengan mendasarkan pada peraturan perundang-undangan secara langsung berubah.

\section{Produk hukum yang dikeluarkan oleh MPR setelah Amandemen UUD 1945}

Kalau dikaji lebih jauh, produk hukum dapat dikeluarkan oleh MPR adalah berupa keputusan dan bukan berupa ketetapan tidak terlepas dari perubahan Undang-Undang Dasar 1945. Perubahan struktur kelembagaan Negara berdasarkan perubahan Undang-Undang Dasar Negara Republik Indonesia tahun 1945, mengakibatkan terjadinya perubahan kedudukan, fungsi, tugas dan wewenang lembaga Negara dan lembaga pemerintahan yang ada. Perubahan tersebut telah mempengaruhi aturan-aturan yang berlaku. Salah satu perubahan tersebut menyangkut produk hukum yang dihasilkan oleh Majelis Permusyawaratan Rakyat (MPR).

Kedudukan MPR pada waktu sebelum perubahan UUD 1945 lebih dilihat sebagai bentuk pendaulatan terhadap keberadaan MPR yang superior. Produk-produk hukum yang dikeluarkan oleh MPR dalam bentuk 'Ketetapan' seakan-akan menyamai kedudukan dari pengaturan UUD sehingga perlu untuk diturunkan desajat pemaknaannya supaya tidak menimbulkan tumpang tindih dan interpretasi yuridis yang menimbulkan kekeliruan dalam penggunaan dan penerapannya. Dengan demikian, bentuk produk hukum MPR berupa keputusan ini sesuai dengan kedudukan MPR yang tidak lagi memegang kedaulatan rakyat. Sifatnya untuk menjadikan produk hukum dalam skala lebih besar seperti ketetapan dan sebagai dasar penjiwaan dari penyusunan produk hukum yang berada di bawahnya sudah dapat diwakili dengan keberadaan Undangundang.

Produk hukum MPR setelah perubahan Undang-Undang Dasar Negara Republik Indonesia tahun 1945 yang mengakibatkan terjadinya perombakan struktural pada tingkatan tata hirarki peraturan perundangundangan di Indonesia. Dalam ketentuan UU No. 10 Tahun 2004 yang menggantikan kedudukan dari Tap MPR No. III Tahun 2000 tidak menempatkan produk MPR dalam tata hirarki. Produk MPR tidak lagi menjadi bagian dan acuan dalam tata hirarki pembuatan peraturan perundang-undangan.

Kewenangan MPR mengeluarkan produk hukum 
berkaitan dengan kedudukan MPR sebagai Lembaga Tinggi Negara yang terdiri dari DPR dan DPD, MPR seakan-akan tidak memiliki organ. Keanggotaan MPR ini disebut sebagai joint session. Namun apakah MPR ini serta merta dapat disebut sebagai sebuah lembaga joint session? Hal ini tentu tidak dapat dikatakan begitu saja, karena sebagai sebuah lembaga joint session, produk hukum yang dihasilkan oleh MPR tentu tidak dapat disebut Ketetapan (TAP) MPR. Secara struktur terbentuknya oleh DPR dan DPD (joint session) hal ini sangatlah rancu. Sebagaimana diketahui bahwa DPD tidak memiliki kewenangan legislasi sebagaimana yang dimiliki oleh DPR pada tataran lembaga perwakilan, namun pada tingkatan lembaga permusyawaratan DPD justru diberikan hak legislasi yang setara dengan DPR. Terjadinya kesalahan kompetensi (dis-competention), di mana salah satu lembaga perwakilan tidak memiliki kewenangan untuk mengeluarkan hak legislasinya. ${ }^{97}$

Keberadaan produk hukum MPR yang berupa ketetapan yang diubah menjadi keputusan MPR telah menimbulkan suatu persoalan baru dalam perihal pengujian terhadap peraturan perundang-undangan yang berada di bawah produk hukum MPR. Meskipun setelah adanya Mahkamah Konstitusi maka hal-hal yang berkaitan dengan judicial terhadap perundang-undangan dilakukan oleh lembaga hukum tersebut. Sedangkan terhadap peraturan perundangundangan di bawah undang-undang

97 Dalam Pasal 22C dan 22D UUD 1945 junto Pasal 41, 42, dan 43 UU No. 22 Tahun 2003 tentang Susunan dan Kedudukan MPR, DPR, DPD dan DPRD, DPD hanya diberikan fungsi dalam mengajukan, membahas Rancangan Undangundang. Ketentuan tersebut tidak menyebutkan tentang kewenangan yang dimiliki oleh DPD dalam bidang pembuatan Undang-undang. dilakukan oleh Mahkamah Agung. Apakah dengan adanya perubahan terhadap keberadaan produk hukum yang dikeluarkan oleh MPR berupa keputusan dapat berakibat pada terjadinya peluang bagi pemanfaatan celah-celah kekosongan lembaga yang berhak untuk menguji setiap peraturan perundang-undangan yang berada di bawah MPR seperti pada pengaturan dalam Ketetapan MPR No. III/MPR/2000 tentang Sumber Hukum dan Tata Urutan Peraturan Perundangundangan.

Ni'matul Huda menjelaskan, bahwa untuk mengisi kekosongan pengaturan tentang kewenangan menguji terhadap undang-undang, MPR dalam sidang tahunan 7-18 Agustus 2000 telah menghasilkan sejumlah ketetapan yang salah satunya adalah Ketetapan MPR Nomor III/MPR/2000 Tentang Sumber Hukum dan Tata Urutan Peraturan Perundang-undangan. Tap ini antara lain mengatur tentang Pertama, sumber hukum dasar nasional Pancasila dan tats urutan peraturan perundangan republik indonesia; kedua, kewenangan MPR menguji undang-undang terhadap UUD 1945 dan Tap MPR serta kewenangan Mahkamah Agung menguji peraturan Perundangundangan di bawah Undang-undang; ketiga, pencabutan dan pernyataan tidak berlakunya lagi Tap. MPRS No. XX/MPRS/1966 Tentang Memorandum DPR-GR mengenai Sumber Tertib Hukum RI dan Tata Urutan peraturan Perundang-undangan RI dan Tap MPR No IX / MPR / 1978 tentang Perlunya Penyempurnaan yang termaktub dalam Pasal 3 ayat (1) TAP MPR RI No V/MPR/1973. ${ }^{98}$

\footnotetext{
98 Ni'matul Huda, Politik Ketatanegaran Indonesia Kajian Terhadap Dinamika Perubahan UUD 1945, FH UII Press, Yogyakarta, 2003, hal 208
} 
Pemberian kewenangan kepada MPR untuk menguji undang-undang, melalui TAP MPR No. III/MPR/2000 didasari oleh pertimbangan; Pertama, perlu adanya lembaga kewenangan untuk menguji undang-undang terhadap UUD dan TAP MPR. Kedua, MPR yang menetapkan UUD dan mengeluarkan produk hukum ketetapan MPR, sehingga lembaga ini dipandang lebih mengerti dan memahami makna maupun hakikat dari materi yang dikandung dalam UUD dan TAP MPR daripada lembaga lain yang tidak menetapkannya. Perlunya lembaga yang diberi wewenang untuk menguji undang-undang sudah lama disampaikan oleh berbagai kalangan masyarakat, karena tidak semua undang-undang yang dihasilkan oleh DPR dan Presiden sesuai dengan kebutuhan masyarakat, atau bahkan ada yang bertentangan dengan aturan yang lebih tinggi. ${ }^{99}$ Sejalan dengan itu, keberadaan produk hukum MPR berupa "Ketetapan" yang menjadi dasar bagi judicial review undangundang terhadap Undang-Undang Dasar oleh MPR, memang perlu untuk digantikan karena telah ada lembaga hukum yang bertugas untuk melakukan judicial review undangundang terhadap UUD yaitu Mahkamah Konstitusi. Menjadi semakin penting kiranya alasan untuk menghilangkan produk MPR yang berupa ketetapan.

Menurut Moh Mahfud MD, hukum merupakan produk politik, maka ia harus diuji apakah substansinya tidak bertantangan dengan kepentingan umum atau kepentingan masyarakat maupun peraturan yang lebih tinggi. Akan tetapi, pemberian wewenang kepada MPR untuk menguji undang-undang dipandang tidak tepat dan justru akan

${ }^{99}$ Ibid, hal. 209 menimbulkan masalah yuridis. Pertama, MPR adalah lembaga politik tempat aspirasi masyarakat diaktualisasikan secara politis dalam rangka pengawasan terhadap kekuasaan pemerintah. Kedua, dari segi keanggotaan anggota MPR adalah juga anggota DPR. Ketiga, pengujian terhadap materil UU lebih mengarah kepada pengujian yuridis daripada pengujian secara politis. Secara politis UU sudah diuji oleh DPR. keempat, kalau suatu peraturan yang lebih rendah bertantangan dengan peraturan yang lebih tinggi, berarti ada perselisihan antara dua hukum. Secara hakiki hal ini adalah sengketa hukum (legal case). ${ }^{100}$ Dari penjelasan ini dapat dikatakan bahwa MPR tidak memiliki kapasitas untuk menyelesaikan persoalan hukum yang berkenaan dengan judicial review undang-undang terhadap UndangUndang Dasar.

Namun demikian, dilihat dari kewenangan yang dimiliki oleh MPR menimbulkan persoalan. Salah satu persoalan yang kemungkinan timbul dari kewenangan MPR yang hanya membuat "Keputusan" berkaitan dengan kewenangan yang diberikan oleh Undang-Undang Dasar terkait dengan perubahan dan penetapan terhadap UIJD 1945. Dalam hal ini MPR telah melakukan kesalahan dan penyimpangan. Kekuatan keputusan MPR dalam menuangkan dan melegitimasi dari penetapan dan perubahan UUD yang merupakan kewenangannya sangat sempit sekali. Konstitusi bersifat "normative closed", artinya perubahan konstitusi tertutup dengan cara-cara di luar peraturan amandemen. Perubahan UUD 1945 dalam bentuk putusan Perubahan UUD adalah menjadikan konstitusi, bersifat

\footnotetext{
${ }^{100}$ Ni'matul Huda. Politik Ketatanegaran Indonesia Kajian Terhadap Dinamika Perubahan UUD 1945, FH UII Press, Yogyakarta, 2003, hal 208 - 211
} 
normative closed sehingga perubahan tidak lagi dilakukan oleh MPR dengan ketetapan MPR.

Adapun produk hukum berupa keputusan Majelis Permusyawaratan Rakyat (MPR) pasca amandemen UUD 1945 adalah sebagai berikut:

1. Keputusan Majelis Permusyawaratan Rakyat Nomor 5/MPR/2003 tentang Penugasan kepada pimpinan majelis permusyawaratan rakyat republik indonesia untuk menyampaikan saran atas laporan pelaksanaan putusan majelis permusyawaratan rakyat republik indonesia oleh Presiden, DPR, BPK, MA pada sidang tahunan Majelis

2. Keputusan Majelis Permusyawaratan Rakyat Nomor 5/MPR/2002 tentang Perubahan jadwal acara sidang tahunan majelis permusyawaratan rakyat republik indonesia tahun 2002

3. Keputusan Majelis Permusyawaratan Rakyat Nomor 4/MPR/2002 tentang Perubahan jadwal acara sidang tahunan majelis permusyawaratan rakyat republik indonesia tahun 2002

4. Keputusan Majelis Permusyawaratan Rakyat Nomor 3/MPR/2002 tentang Komposisi keanggotaan komisi A, B, dan C Majelis Permusyawaratan rakyat Republik Indonesia pada sidang tahunan Majelis Permusyawaratan Rakyat Republik Indonesia tahun 2002

5. keputusan majelis permusyawaratan rakyat nomor 1/mpr/2002 tentang jadwal acara sidang tahunan Majelis Permusyawaratan Rakyat Republik Indonesia tahun 2002

\section{Penutup}

\section{Kesimpulan}

a. Kedudukan TAP MPR dalam Urutan Perundang-undangan merupakan sumber hukum dan memiliki tata hirarki dalam peraturan perundang-undangan yang berlaku, karena Undang Undang Nomor 12 tahun 2011 tentang Pembentukan Peraturan Perundang-undangan telah menempatkan kembali Ketetapan MPR dalaam tata urutan peraturan perundang undangan.

2. Produk hukum yang dapat dikeluarkan MPR setelah Amandemen UUD 1945 adalah berupa Keputusan Majelis Permusyawaratan Rakyat Keputusan MPR, karena adanya perubahan terhadap kedudukan dan fungsi, tugas dan wewenang MPR. MPR sudah tidak lagi sebagai lembaga tertinggi negara namun MPR merupakan lembaga Negara gabungan (joint session) antara Dewan Perwakilan Rakyat (DPR) dan dewan Perwakilaan Daerah (DPD).

\section{Saran}

a. Perlu segera dilakukan realisasi terhadap beberapa Ketetapan MPR yang sekiranya akan dijadikan sebagai Undang-undang agar instruksi yang diberikan kepada DPR dapat diwujudkan

b. Perlu adanya keseimbangan dalam kewenangan yang dimiliki oleh DPD sehingga keutuhan terhadap produk hukum yang dikeluarkan oleh MPR merupakan satu kesatuan lembaga perwakilan.

c. Perlu adanya peran serta dari masyarakat untuk memberikan kajian dan masukan terhadap kedudukan Ketetapan MPR setelah adanya perubahan UUD 1945.

\section{DAFTAR PUSTAKA}

\section{A. LITERATUR}

Azhary, Negara Hukum Indonesia, Analisa Yuridis Normatif tentang unsur-unsurnya, UI Press, Jakarta, 1995

Johnny Ibrahim, Teori \& Metode Penelitian Hukum Normatif, Banyumedia Publishing, Malang 2006.

Peter Mahmud Marzuki. Penelitian Hukum. Universitas Air Langga. Surabaya. 
Ni'matul Huda. Politik Ketatanegaran

Indonesia Kajian Terhadap Dinamika Perubahan UUD 1945, FH UII Press, Yogyakarta, 2003.

C.S.T. Kansil dan Christine S. T. Kansil, Hukum Tata Negara Republik Indonesia I. Rineka Cipta. Jakarta, 2000. Cetakan Ketiga.

B. PERATURAN PERUNDANG UNDANGAN

Undang Undang Dasar 1945

Undang Undang Nomor 12 Tahun 2011

Undang Undang Nomor 17 Tahun 2014. 


\title{
TINJAUAN YURIDIS ASAS SUBSIDIARITAS YANG DIUBAH MENJADI ASAS ULTIMUM REMEDIUM DALAM PENEGAKAN HUKUM PIDANA LINGKUNGAN
}

\begin{abstract}
ABSTRAK
. Dalam penyelenggaraan pengelolaan lingkungan hidup sebagai upaya pembangunan berkelanjutan yang berwawasan lingkungan hidup, harus didasarkan pada norma hukum dengan memperhatikan tingkat kesadaran masyarakat dan perkembangan lingkungan global serta perangkat hukum internasional yang berkaitan dengan lingkungan hidup. Kesadaran dan kehidupan masyarakat dalam kaitannya dengan pengelolaan lingkungan hidup telah berkembang sedemikian rupa sehingga perlu disempurnakan untuk mencapai tujuan pembangunan berkelanjutan yang berwawasan lingkungan hidup. Penelitian ini bertujuan memahami dan menganalisis secara yuridis asas subsidiaritas yang di ubah menjadi asas ultimum remedium dalam penegakan hokum pidana lingkungan.. Tipe penelitian ini adalah penelitian hukum normatif yang bersumber pada data sekunder dan metode pengumpulan serta pengolahan data dengan studi kepustakaan.

Penyelesaian sengketa lingkungan hidup dapat ditempuh melalui pengadilan atau di luar pengadilan. Di pengadilan melalui hukum administrasi, hukum perdata dan hukum pidana. Di luar pengadilan melalui mediasi, litigasi dan arbitrasi.

Asas subsidiaritas yang diatur dalam UU no 23 Tahun1997 (UUPLH) telah diubah menjadi asas ultimum remedium seperti yang ditegaskan dalam UU No 32 Tahun 2009. Pada dasarnya kedua asas tersebut sama yaitu tidak langsung menerapkan sanksi pidana dalam penegakan hukum lingkungan. Perbedaannya asas subsidiaritas merupakan preventif dalam penegakan hukum pidana lingkungan, tetapi asas ultimum remedium dapat langsung diterapkan apabila pelanggaran dilakukan lebih dari satu kali terhadap baku mutu air limbah, baku mutu emisi, atau baku mutu gangguan.

Asas ultimum remedium mempunyai kelemahan yaitu dalam penafsiran penegakan hukum administrasi dianggap tidak berhasil karena sanksi administrasi terdiri dari teguran tertulis, paksaan pemerintah, pembekuan izin lingkungan, atau pencabutan izin lingkungan.

Akhirnya penegakan hukum lingkungan hendaknya dilakukan secara optimal baik melalui pengadilan maupun di luar pengadilan ,sehingga kasus penecenaran dan atau perusakan lingkungan dapat ditekan. Disamping itu asas subsidiaritas dan asas ultimum remedium diperjelas pengertiannya sehingga tidak salah tafsir.
\end{abstract}

Kata Kunci : Asas Subsidiaritas, Asas Ultimum Remedium, Penegakan Hukum Pidana ungan

\section{PENDAHULUAN}

Hakikat pembangunan nasional sesungguhnya tertuju pada manusia, yaitu membangun manusia Indonesia seutuhnya yang bercirikan keselarasan hubungan manusia dengan Tuhan, keselarasan hubungan individu dengan masyarakat dan keselarasan hubungan manusia dengan lingkungan alam. Bertolak dari pemikiran tersebut di atas, maka pembangunan yang dilaksanakan di Indonesia tidak memisahkan antara pembangunan material dengan pengembangan lingkungan hidup. Lingkungan hidup sebagai karunia dan rahmat Tuhan Yang Maha Kuasa kepada rakyat dan bangsa Indonesia merupakan ruang bagi kehidupan dalam segala aspek dan matranya sesuai dengan wawasan nusantara.

Dalam rangka mendayagunakan sumber daya alam untuk memajukan kesejahteraan umum seperti diamanatkan dalam UndangUndang Dasar Negara Republik Indonesia Tahun 1945 dan untuk mencapai kebahagiaan 
hidup berdasarkan Pancasila, maka perlu dilaksanakan pembangunan berkelanjutan yang berwawasan lingkungan hidup, berdasarkan kebijaksanaan nasional yang terpadu dan menyeluruh dengan memperhitungkan kebutuhan generasi masa kini dan generasi masa mendatang. Untuk itu dipandang perlu melaksanakan pengelolaan lingkungan hidup yang serasi, selaras, dan seimbang guna menunjang terlaksananya pembangunan berkelanjutan yang berwawasan lingkungan hidup. Dalam penyelenggaraan pengelolaan lingkungan hidup sebagai upaya pembangunan berkelanjutan yang berwawasan lingkungan hidup, harus didasarkan pada norma hukum dengan memperhatikan tingkat kesadaran masyarakat dan perkembangan lingkungan global serta perangkat hukum internasional yang berkaitan dengan lingkungan hidup. Kesadaran dan kehidupan masyarakat dalam kaitannya dengan pengelolaan lingkungan hidup telah berkembang sedemikian rupa sehingga perlu disempurnakan untuk mencapai tujuan pembangunan berkelanjutan yang berwawasan lingkungan hidup.

Beberapa dekade terakhir ini, masalah lingkungan hidup semakin marak menjadi isu sosial ekonomi dan bahkan juga politik. Masalah lingkungan hidup apabila dikaitkan dengan masalah hak-hak asasi manusia tidak saja merupakan persoalan negara per negara tetapi juga menjadi persoalan dunia internasional. Hal tersebut tidaklah berlebihan, sebab hak untuk memperoleh lingkungan hidup yang sehat merupakan salah satu hal asasi yang diatur di dalam Universal Declaration of Human Right 1948.

Atas dasar hal tersebut di atas, Pemerintah Indonesia memandang perlu untuk menerbitkan peraturan perundang-undangan yang khusus mengatur tentang pengelolaan lingkungan hidup. Pada tahun 1982 Pemerintah Indonesia telah menerbitkan Undang-Undang Nomor 4 Tahun 1982 tentang Ketentuan-ketentuan Pokok Pengelolaan Lingkungan Hidup (UULH) yang berlaku kurang lebih selama 15 tahun, kemudian disempurnakan melalui penerbitan UndangUndang Nomor 23 Tahun 1997 tentang
Pengelolaan Lingkungan Hidup (UUPLH). Selanjutnya pada 3 Oktober 2009 UUPLH telah dirubah menjadi Undang-Undang Nomor 32 Tahun 2009 tentang Perlindungan dan Pengelolaan Lingkungan Hidup (UUPPLH). UUPPLH tersebut berlaku sebagai paying atau umbrella act atau umbrella provision atau dalam ilmu hukum disebut kaderwet atau raamwet, sebab hanya diatur ketentuan pokoknya saja.Lingkungan hidup menurut Pasal 1 angka 1 Undang-Undang Nomor 32 Tahun 2009 adalah kesatuan ruang dengan semua benda, daya, keadaan dan makhluk hidup, termasuk manusia dan perilakunya, yang mempengaruhi alam itu sendiri, kelangsungan perikehidupan dan kesejahteraan manusia serta makhluk hidup lain.

Sesuai dengan hakikat Negara Republik Indonesia sebagai negara hukum, maka pengembangan sistem pengelolaan lingkungan hidup di Indonesia haruslah diberi dasar hukum yang jelas, tegas dan menyeluruh guna menjamin kepastian hukum bagi usaha pengelolaan tersebut. Dasar hukum tersebut dilandasi oleh prinsip hukum lingkungan dan pentaatan setiap orang akan prinsip tersebut yang keseluruhannya berlandaskan wawasan nusantara.

Dengan demikian, dalam rangka pelestarian lingkungan hidup, pemerintah menyediakan sarana-sarana hukum yang bertujuan untuk mengatur dan mengelola lingkungan hidup tersebut yang selanjutnya disebut hukum lingkungan. Hukum lingkungan perlu ditegakkan terhadap perbuatan-perbuatan yang melanggarnya. Penegakan hukum lingkungan dapat dilaksanakan dengan 3 (tiga) cara, yaitu melalui hukum administrasi, hukum perdata dan hukum pidana dimana masing-masing dengan sanksi berupa sanksi adminitratif, sanksi perdata dan sanksi pidana. Dalam hal penegakan hukum lingkungan dengan sarana hukum pidana atau pertanggungjawaban hukum pidana, patut kiranya dikemukakan bahwa penggunaan sanksi hukum pidana sebagai sarana penanggulangan delik-delik lingkungan lebih bersifat subsidiar, bukan sebagai sarana yang primair. 
Dengan perkataan lain, sebagai penunjang hukum administrasi, berlakunya ketentuan pidana tetap memperhatikan asas subsidiaritas, bahwa hukum pidana hendaknya didayagunakan apabila sanksi bidang hukum lain, seperti sanksi administrasi dan sanksi perdata dan alternatif penyelesaian sengketa lingkungan hidup tidak efektif, atau tingkat kesalahan pelaku relatif berat, atau perbuatannya menimbulkan keresahan masyarakat.

Keberadaan asas subsidiaritas pidana dalam penegakan tindak pidana lingkungan sejak awal telah mengandung kelemahan dalam penerapannya. Sistem perumusan pada penjelasan tidak jelas sehingga menyulitkan dalam praktik. Untuk memperbaikinya maka berdasarkan UUPPLH asas subsidiaritas diubah menjadi asas ultimum remedium. Berdasarkan hal tersebut, penulis berkeinginan untuk melakukan pengkajian secara mendalam baik mengenai asas subsidiaritas maupun asas ultimum remedium dan pengaruhnya terhadap penegakan hukum pidana lingkungan.

\section{LANDASAN TEORI}

\section{A. Asas-asas hukum Lingkungan}

Dalam hukum lingkungan dikenal beberapa asas yaitu asas subsidiaritas, asas ultimum remedium, asas precautionary, asas subsosialitas dan asas in dubio pro reo.

\section{Asas Subsidiaritas}

Kata subsidiaritas dalam kamus Inggris Indonesia Jhohn Echols dan Hassan Shadily ditemukan kata "subsidiary" yang mengandung makna cabang, tambahan. Demikian pula dalam kamus hukum di dapatkan kata subsidair yang bermakna sebagai pengganti, tambahan, jika hal pokok tidak terjadi atau dapat dilakukan, maka sebagai penggantinya. Dalam kamus umum Belanda Indonesia ditemukan kata subsidiair mengandung arti sebagai ganti, atau. Sedangkan pada Black's Law Dictionary subsidiary berarti subordínate, under another's control.
Asas subsidiaritas tercantum dalam penjelasan umum pada angka 7 dari Undangundang Nomor 23 tahun 1997 tentang Pengelolaan Lingkungan Hidup :

"bahwa sebagai penunjang hukum administrasi, maka berlakunya ketentuan hukum pidana tetap memperhatikan asas subsidiaritas, yaitu bahwa hukum pidana hendaknya didayagunakan apabila sanksi hukum lain, seperti sanksi administrasi dan sanksi perdata, dan alternatif penyelesaian sengketa lingkungan hidup sudah dinyatakan tidak efektif, dan/atau tingkat kesalahan pelaku relatif berat, dan/atau perbuatannya relatif besar dan/atau perbuatannya menimbulkan keresahan masyarakat".

Penegakan hukum pidana bersifat subsidiaritas berarti penegakan hukum pidana semata-mata guna menunjang penegakan hukum administrasi dan/atau penegakan hukum perdata baik yang diselesaikan di Pengadilan maupun melalui mediasi atau konsiliasi. Manakala penegakan hukum administrasi maupun hukum perdata tadi sudah tidak efektif pelaksanaannya barulah dioperasionalkan penegakan hukum pidana.

Inilah yang dimaksudkan dengan penerapan hukum pidana tetap memperhatikan asas subsidiaritas karena dalam hal-hal yang telah disebutkan di atas, fungsi hukum pidana hanya sebagai penunjang hukum administrasi, hukum perdata di Pengadilan dan di luar Pengadilan melalui Mekanisme Alternatif Penyelesaian Sengketa (MAPS). Dengan asas subsidiaritas pendayagunaan instrumen pidana adalah sebagai cabang (bukan pokok) atau berupa tambahan atau pengganti apabila pendayagunaan instrumen hukum administrasi dan hukum perdata serta penyelesaian sengketa tidak efektif.

\section{Asas Precautionary (Precautionary Principle) \\ Dari asas subsidiaritas ini dalam} penerapannya terkandung asas precautionary (Precautionary Principle). Precautionary dalam kamus Inggris Indonesia tersebut bermakna, yang berhubungan dengan pencegahan atau tindakan pencegahan. Dengan demikian pencegahan lebih 
didahulukan dan diutamakan dari penindakan. Sedangkan apabila akan dilakukan penindakan harus dilakukan secara bertahap dari tindakan yang teringan, tindakan sedang dan terakhir dengan tindakan berat.

Prinsip precautionary ini dapat kita jumpai pada prinsip nomor 15 deklarasi rio (Rio Declaration on Environment and Development, 1992), yang memuat 21 prinsip untuk membangun kerjasama global yang baru dan seimbang melalui kerjasama antar negara. Deklarasi rio ini telah mengadopsi beberapa prinsip yang sebelumnya terdapat dalam deklarasi Stockholm 1972 (Stockholm Declaration on The Human Environment) yang mengamanatkan pembangunan yang berkelanjutan (sustainable development) sebagai basis aksi global, regional dan lokal.

Asas atau prinsip ini mengandung pengertian bahwa tindakan pencegahan atau perlindungan lebih baik daripada tindakan pemulihan, serta kekurangan ilmu pengetahuan bukanlah suatu alasan untuk melakukan pencegahan terhadap perbuatanperbuatan yang potensial merugikan lingkungan. Prinsip ini mendorong untuk bertindak cepat dan tepat (tidak menunda) sebagai upaya pencegahan walaupun terdapat kelangkaan dan kurangnya pembuktian atau ketersediaan data ilmiah yang memadai. Asas atau prinsip 15 dari Deklarasi Rio ini lebih tepat digunakan dalam hukum perdata, karena pertanggung jawaban tanpa pembuktian adanya unsur kesalahan.

Sedangkan untuk hukum pidana maka asas precautionary ini mengandung makna bahwa pencegahan lebih didahulukan dan diutamakan dari penindakan. Kalau penindakan yang dilakukan, maka penerapannya dilakukan secara bertahap, tidak langsung dikenakan penindakan yang terberat, yaitu dilakukan secara bertahap dan berjenjang, dari penindakan yang teringan, dan bila pelanggaran tetap dilakukan maka akan dikenakan sanksi yang lebih berat, demikian selanjutnya. Prinsip precautionary menghendaki tindakan pencegahan atau pengawasan dari instansi terkait harus lebih dikedepankan (hukum administrasi) dibandingkan dengan penindakan hukum pidana. Akan tetapi menurut Daud Silalahi prinsip ini tidak jelas posisinya dalam Undangundang No 23 tahun 1997.

\section{Asas Ultimum Remedium}

Kesulitan atau hambatan asas subsidiaritas pada praktik penegakan hukum pada UUPLH telah diperbaiki pada UUPPLH dengan mengubah asas subsidiaritas menjadi asas ultimum remedium yang dinyatakan pada penjelasan umum UUPPLH angka 6 sebagai berikut : "Penegakan hukum pidana lingkungan tetap memperhatikan asas ultimum remedium yang mewajibkan penerapan penegakan hukum pidana sebagai upaya terakhir setelah penerapan penegakan hukum administrasi dianggap tidak berhasil. Penerapan asas ultimum remedium ini hanya berlaku bagi tindak pidana formil tertentu, yaitu pemidanaan terhadap pelanggaran baku mutu air limbah, emisi dan gangguan”.

Ultimum mengandung makna paling akhir atau terakhir, sedangkan kata remedium ditemukan berasal dari kata remedy yang mengandung makna obat atau memperbaiki. Apabila ultimum remedium dikaitkan dengan penegakan hukum pidana lingkungan, maka harus dimaknai bahwa hukum administrasi dinyatakan tidak berhasil barulah hukum pidana didayagunakan sebagai upaya terakhir dalam memperbaiki lingkungan. Dengan demikian dalam kerangka operasionalisasi hukum pidana dikaitkan dengan asas ultimum remedium jauh lebih tegas dibandingkan operasionalisasi asas subsidiaritas pada UUPLH. Hanya saja UUPPLH sangat membatasi dengan delik formil (yang berkaitan dengan hukum administrasi) tertentu saja, padahal masih banyak delik formil yang lain namun justru hukum pidana didayagunakan secara primum remedium.

\section{Asas Subsosialitas}

Makna asas subsosialitas (subsocialiteit) adalah hakim dapat tidak menjatuhkan pidana walaupun terdakwa telah terbukti dan dinyatakan bersalah, jika delik itu terlalu ringan atau melihat keadaan pada waktu perbuatan dilakukan atau sesudah perbuatan 
dilakukan. Asas subsosialitas ini berkaitan langsung dengan asas ultimum remedium.

Menurut Syahrul Machmud dalam hukum pidana modern, terhadap terdakwa tidak selalu dijatuhi pidana penjara, karena banyak hukuman alternatif lain yang dapat diterapkan pada terdakwa, hal ini telah tercantum dalam RUU-KUHP. Meski demikian di Indonesi belum diterapka hukum pidana modern, terbukti dari UUPPLH yang baru, selalu menerapka pidana penjara pada terdakwa, bahkan kepada pejabat yang tidak melaksanakan tugasnya dengan baik dapat dipidana penjara pula. Sehingga akibatnya seluruh lembaga pemasyarakatan kelebihan penghuni (over capacity). Keadaan semacam ini sesungguhnya kurang menguntungkan bagi perkembangan hukum pidana itu sendiri.

\section{Asas In Dubio Pro Reo}

Sejak UUPPLH diundangkan pada 3 oktober 2009, maka telah terjadi perubahan undang-undang pada hukum lingkungan. Apakah penggantian asas subsidiaritas oleh asas ultimum remedium dapat mempengaruhi penerapan delik formal pada penegakan hukum pidana lingkungan. Bagaimana perlakuan hukum pidana terhadap perubahan undang-undang tersebut.

Sanksi pidana pada UUPPLH lebih berat bila dibandingkan dengan UUPLH, karena pada UUPPLH dikenal sanksi minimal dan denda minimal serta sanksi pidana yang jauh lebih berat bila dibandingkan dengan UUPLH. Demikian pula perlakuan terhadap delik formal kecuali pada pelanggaran baku mutu air limbah, baku mutu emisi, dan baku mutu gangguan, semuanya diterapkan langsung hukum pidana atau hukum pidana difungsikan primum remedium. Sedangkan pada UUPLH pada delik formal hukum pidana difungsikan secara ultimum remedium.

Dengan demikian bila pelanggaran hukum lingkungan dilakukan sebelum UUPPLH diundangkan, maka pelanggarnya tetap dikenakan UUPLH karena lebih ringan, hal ini dikenal dengan asas in dubio pro reo atau dikenakan hal yang menguntungkan/meringankan terdakwa.

\section{B.Penegakan Hukum Pidana Lingkungan (environmental enforcement)}

Makna penegakan hukum atau law enforcement atau rechthandhaving khususnya terhadap penegakan hukum pidana sebagaimana yang dirumuskan dalam Seminar Hukum Nasional 1980 dinyatakan : "Penegakan hukum pidana diarahkan kepada perlindungan masyarakat dari kejahatan serta keseimbangan dan keselarasan hidup dalam masyarakat dengan memperhatikan kepentingan-kepentingan masyarakat/ negara, korban dan pelaku".

Satjipto Rahardjo menjelaskan bahwa hakekat dari penegakan hukum adalah suatu proses untuk mewujudkan keinginankeinginan atau ide-ide hukum menjadi kenyataan. Keinginan-keinginan hukum adalah pikiran-pikiran badan pembentuk UU yang berupa ide atau konsep-konsep tentang keadilan, kepastian hukum dan kemanfaatan sosial yang dirumuskan dalam peraturan hukum itu. Dengan kata lain penegakan hukum adalah suatu proses untuk mewujudkan keinginan hukum menjadi kenyataan.

Pengertian penegakan hukum lingkungan menurut Tim Penyusun Kebijaksanaan Strategi dan Rencana Aksi Pengelolaan Lingkungan Hidup Kantor Menteri Negara Lingkungan Hidup, bahwa penegakan hukum lingkungan hidup adalah tindakan untuk menerapkan perangkat hukum melalui upaya pemaksaan sanksi hukum guna menjamin ditaatinya ketentuan-ketentuan yang termuat dalam peraturan perundang-undangan lingkungan hidup.

Menurut Soerjono Soekanto agar upaya penegakan hukum berjalan dengan baik dan sempurna, maka paling sedikit harus ada empat faktor yang harus dipenuhi :

1. Kaedah hukum atau peraturan itu sendiri.

2. Petugas yang menerapkan atau menegakkan.

3. Fasilitas yang diharapkan akan dapat mendukung pelaksanaan kaedah hukum.

4. Warga masyarakat yang terkena ruang lingkup peraturan tersebut. 
Agar penegakan hukum dapat berjalan sesuai dengan yang diinginkan, maka keempat elemen tersebut harus berjalan seiring dan serasi. Karena masing-masing elemen saling menunjang dan melengkapi, sehingga bila salah satu elemen kurang serasi maka akan sangat mempengaruhi elemen lainnya, dan terjadilah ketimpangan dalam upaya penegakan hukum tersebut.

Terhadap elemen ketiga tentang fasilitas yang diharapkan dapat mendukung pelaksanaan kaedah hukum, ternyata pemerintah pusat maupun pemerintah daerah belum mengganggarkan dana khusus untuk melakukan uji klinis atas limbah yang dibuang oleh pihak industri secara teratur. Karena penanggulangan masalah lingkungan memerlukan dana yang cukup besar, selain penguasaan ilmu pengetahuan dan teknologi lingkungan serta managemen lingkungan, dan oleh karenanya diperlukan sarana dan prasarana yang cukup memadai. Perlu disadari bahwa penegakan hukum lingkungan lebih spesifik dan rumit, maka agar penegakan hukum lingkungan ini dapat berdaya guna dan berhasil guna perlu didukung oleh laboratorium yang memadai dengan tenaga yang profesional, serta dukungan dana yang tidak kecil. Dengan demikian aparat penegak hukum administrasi dapat melakukan tugas dan fungsinya secara teratur sehingga dapat dicegah kerusakan lingkungan sebelum semakin menjadi rusak/parah. Kenyataan yang terjadi selama ini adalah, manakala masyarakat telah resah akibat alam tercemar, barulah aparat pemerintah tururn tangan.

Kelemahan dari keempat faktor tersebut terhadap masalah lingkungan jelas sangat besar pengaruhnya, kelemahan tersebut menjadikan penegakan hukum lingkungan kita semakin tidak berdaya.

Sedangkan Satjipto Rahardjo menyatakan, bahwa penegakan hukum mengandung pilihan dan kemungkinan, oleh karenanya dihadapkan pada masalah yang kompleks, baik pada tahap aplikasinya maupun pada tahap formulasi. Karena kondisinya tidak steril maka dalam proses penegakannya juga dapat dihinggapi berbagai permasalahan baik yang positif maupun negatif, dipengaruhi oleh berbagai kepentingan baik kepentingan pembuat Undang-undang, kepentingan pelaksana Undang-undang, dan kepentingan dari unsur-unsur yang terdapat di dalam proses penegakan hukum tampaknya memegang peran dominan.

Istilah pidana dalam tulisan ini terfokus pada penegakan hukum pidana berkaitan dengan asas susidiaritas atau asas ultimum remedium yang berkaitan dengan asas precautionary yang memiliki sifat khas, berbeda dengan penerapan hukum pidana biasa.

Penegakan hukum pidana lingkungan merupakan serangkaian kegiatan dalam upaya tetap mempertahankan lingkungan hidup dalam keadaan lestari yang memberi manfaat bagi generasi masa kini dan juga generasi masa depan. Upaya tersebut sangat komplek dan banyak sekali kendala dalam tataran aplikatif.

Penerapan hukum pidana dikaitkan dengan asas subsidiaritas yang diganti asas ultimum remedium dengan delik formil, maka hukum administrasi harus didayagunakan terlebih dahulu. Apabila penegakan hukum administrasi tidak efektif barulah penegakan hukum pidana didayagunakan.

Khusus untuk UUPPLH pengaturan tentang penyidik lingkungan diatur dalam pasal 94 dan pasal 95.

Pasal 94 UUPPLH menyebutkan :

Ayat (1) :Selain Penyidik Pejabat Kepolisian Negara Republik Indonesia, juga Pejabat Pegawai Negeri Sipil tertentu dilingkungan instansi pemerintah yang lingkup tugas dan tanggung jawabnya dibidang perlindungan dan pengelolaan lingkungan hidup diberi wewenang sebagai penyidik sebagaimana dimaksud dalam Hukum Acara Pidana untuk melakukan penyelidikan tindak pidana lingkungan hidup.

Ayat (4) : Dalam hal penyidik pejabat pegawai negeri sipil melakukan yaitu bahwa 
hukum pidana hendaknya didayagunakan apabila sanksi hukum lain, seperti sanksi administrasi dan sanksi perdata, dan alternatif penyelesaian sengketa lingkungan hidup sudah dinyatakan tidak efektif, dan/atau tingkat kesalahan pelaku relatif berat, dan/atau perbuatannya relatif besar dan/atau perbuatannya menimbulkan keresahan masyarakat". penyidikan, penyidik pejabat pegawai negeri sipil memberitahukan kepada penyidik pejabat polisi Negara Republik Indonesia dan penyidik pejabat polisi Negara Republik Indonesia memberikan bantuan guna kelancaran penyidikan.

Ayat (5) : Penyidik pejabat pegawai negeri sipil meberitahukan dimulainya penyidikan kepada penuntut umum dengan tembusan kepada penyidik pejabat polisi Negara Republik Indonesia

Ayat (6) : Hasil penyidikan yang telah dilakukan oleh penyidik pegawai negeri sipil disampaikan kepada penuntut umum.

Pasal 95 UUPPLH menyebutkan :

Ayat (1) : Dalam rangka penegakan hukum terhadap pelaku tindak pidana lingkungan hidup, dapat dilakukan penegakan hukum terpadu antara penyidik pegawai negeri sipil, kepolisian, dan kejaksaan di bawah koordinasi Menteri.

Oleh karena itu penegakan hukum pidana lingkungan pada dasarnya dapat dibagi menjadi beberapa tahapan yaitu tahapan preemtive, tahapan preventif dan tahapan represif. Tahapan pre-emtive adalah suatu proses antisipatif di mana upaya deteksi lebih awal berbagai faktor pencetus pencemarandan/atau perusak lingkungan. Tahapan preventif adalah serangkaian tindakan nyata dengan tujuan pencegahan pencemaran dan/atau perusakan lingkungan. Tahapan represif adalah penindakan dari aparat penegak hukum pidana terhadap pelaku atas pelanggaran hukum berupa pencemaran dan/atau perusakan lingkungan

\section{METODOLOGI}

Penelitian hukum ini menggunakan tipe penelitian hukum normatif. "Menurut Soerjono Soekanto, penelitian hukum normatif merupakan penelitian hukum kepustakaan, yaitu dengan meneliti bahan pustaka sebagai data sekunder. Tipe penelitian hukum normatif didasari oleh kerangka konsepsional dan kerangka teoritis, juga terdiri dari penelitian terhadap asas-asas hukum, sistematik hukum dan taraf sinkronisasi vertikal maupun horisontal."

\section{PEMBAHASAN}

Asas subsidiaritas dalam UU No. 23 Tahun 1997 yang lalu telah dihapus pada UU No. 32 Tahun 2009, diganti dengan asas ultimum remedium.

Asas subsidiaritas yaitu bahwa hukum pidana hendaknya didayagunakan apabila sanksi hukum lain, seperti sanksi administrasi dan sanksi perdata, dan alternatif penyelesaian sengketa lingkungan hidup sudah dinyatakan tidak efektif, dan/atau tingkat kesalahan pelaku relatif berat, dan/atau perbuatannya relatif besar dan/atau perbuatannya menimbulkan keresahan masyarakat".

Dalam pasal 30 UU No 23 Tahun 1997 di sebutkan bahwa :

1. Penyelesaian sengketa lingkungan hidup dapat ditempuh melalui pengadilan atau di luar pengadilan berdasarkan pilihan secara sukarela para pihak yang bersengketa.

2. Penyelesaian sengketa di luar pengadilan sebagaimana dimaksud pada ayat (1) tidak berlaku terhadap tindak pidana lingkungan hidup sebagaimana diatur dalam Undangundang ini.

3. Apabila telah dipilih upaya penyelesaian sengketa lingkungan hidup di luar pengadilan, gugatan melalui pengadilan 
hanya dapat ditempuh apabila upaya tersebut dinyatakan tidak berhasil oleh salah satu atau para pihak yang bersengketa.

Sedangkan dalam pasal 84 UU No. 32 Tahun 2009 dinyatakan bahwa :

(1) Penyelesaian sengketa lingkungan hidup dapat ditempuh melalui pengadilan atau di luar pengadilan.

(2) Pilihan penyelesaian sengketa lingkungan hidup dilakukan secara suka rela oleh para pihak yang bersengketa.

(3) Gugatan melalui pengadilan hanya dapat ditempuh apabila upaya penyelesaian sengketa di luar pengadilan yang dipilih dinyatakan tidak berhasil oleh salah satu atau para pihak yang bersengketa.

Asas ultimum remedium mewajibkan penerapan penegakan hukum pidana sebagai upaya terakhir setelah penerapan penegakan hukum administrasi dianggap tidak berhasil. Penerapan asas ultimum remedium ini hanya berlaku bagi tindak pidana formil tertentu, yaitu pemidanaan terhadap pelanggaran baku mutu air limbah, emisi dan gangguan”.

Asas ini lebih dipertegas pemaknaannya dalam pasal 100 ayat (2) UUPPLH yaitu, setiap orang yang melanggar baku mutu air limbah, baku mutu emisi, atau baku mutu gangguan baru dapat dipidana, jika sanksi administrasi yang telah dijatuhkan tidak dipatuhi atau pelanggaran dilakukan lebih dari satu kali mengapa tidak dilakukan tindakan penegakan hukum administrasi sebagai upaya preventif, tetapi langsung diterapkan hukum pidana. Kelemahan mendasar ini dapat dipastikan pada penegakan hukum pidana pada UUPPLH akan mengalami hambatan seperti pada UUPLH yang lalu.

Namun bila dicermati penjelasan umum UUPPLH pada angka 6 tentang asas ultimum remedium tetap mengandung kelemahan mendasar. Karena penjelasan umum dalam UUPPLH sangat tidak memadai untuk dijadikan pedoman dalam tataran aplikatif. Karena dalam tataran aplikatif sangat diperlukan aturan pelaksana yang sangat jelas dan detail dan harus dihindarkan multi tafsir atau debattable dalam memaknai suatu ketentuan. Kelemahan dalam tataran formulatif tersebut jelas akan menimbulkan banyak masalah pada tataran aplikatif, seperti tidak adanya kepastian hukum dan akan banyak menimbulkan masalah pada bidang koordinasi antar institusi terkait dalam penanganan masalah pencemaran dan/atau perusakan lingkungan.

UUPPLH mewajibkan penerapan penegakan hukum pidana terhadap delik formil tertentu sebagai upaya terakhir, setelah hukum administrasi dianggap gagal atau pelanggaran telah dilakukan lebih dari satu kali. Konsekuensi yuridis dari kata wajib ini adalah batal demi hukum bila tidak ditaati. Konkritisasi dari hukum administrasi dianggap gagal tersebut, tidak ada penjelasan lebih lanjut.

\section{PENUTUP}

\section{Kesimpulan}

1. Penyelesaian sengketa lingkungan hidup dapat ditempuh melalui pengadilan atau di luar pengadilan. Di pengadilan melalui hukum administrasi, hukum perdata dan hukum pidana. Di luar pengadilan melalui mediasi, litigasi dan arbitrasi.

2. Asas subsidiaritas yang diatur dalam UU no 23 Tahun1997 (UUPLH) telah diubah menjadi asas ultimum remedium seperti yang ditegaskan dalam UU No 32 Tahun 2009. Pada dasarnya kedua asas tersebut sama yaitu tidak langsung menerapkan sanksi pidana dalam penegakan hukum lingkungan. Perbedaannya asas subsidiaritas merupakan preventif dalam penegakan hukum pidana lingkungan, tetapi asas ultimum remedium dapat langsung diterapkan apabila pelanggaran dilakukan lebih dari satu kali terhadap baku mutu air limbah, baku mutu emisi, atau baku mutu gangguan.

3. Asas ultimum remedium mempunyai kelemahan yaitu dalam penafsiran penegakan hukum administrasi dianggap tidak berhasil karena sanksi administrasi terdiri dari teguran tertulis, paksaan 
pemerintah, pembekuan izin lingkungan, atau pencabutan izin lingkungan.

\section{Saran}

1. Penegakan hukum lingkungan hendaknya dilakukan secara optimal baik melalui pengadilan maupun di luar pengadilan,sehingga kasus penecenaran dan atau perusakan lingkungan dapat ditekan.

2. Asas subsidiaritas dan asas ultimum remedium masih perlu disosialisasikan agar lebih dapat di pahami penerapannya

3. Harus ada kejelasan asas ultimum remedium dalam penegakan hukum administrasi sehingga ada kepastian berapa kali dan berapa lama tindakan administrasi baru dapat dikatakan tidak berhasil. Apakah setelah mendapat teguran tertulis sebagai sanksi administrasi yang paling rendah dan tidak dipatuhi sudah dinyatakan dianggap tidak berhasil ? Bagaimana pula makna pelanggaran dilakukan lebih dari satu kali, apakah cukup dua kali saja ataukah tiga kali atau lebih.

\section{DAFTAR PUSTAKA}

\section{A. BUKU-BUKU}

Andi Hamzah, Penegakan Hukum

Lingkungan, Sinar Grafika, Jakarta, 2005

Barda Nawawi, Kebijakan Hukum Pidana,

Kencana Prenada Media Group, Jakarta, 2008

Joni Emirzon, Alternatif Penyelesaian

Sengketa Di Luar Pengadilan, PT

Gramedia Pustaka Utama, Jakarta, 2001

Peter Mahmud, Penelitian Hukum, Kencana Prenada Media Grup, 2005

Philipus M. Hadjon, (Koordinator Tim), Pengantar Hukum Administrasi Indonesia, Gajah Mada University Press, Yogyakarta, 2005
Satjipto Rahardjo, Masalah Penegakan

Hukum, Suatu Tinjauan Sosiologis, Sinar Baru, Bandung.

Syahrul Machmud, Penegakan Hukum

Lingkungan Indonesia, Graha Ilmu, Yogyakarta, 2012.

\section{B. PERATURAN DAN PERUNDANG- UNDANGAN.}

Undang-Undang No 23 Tahun 1997 tentang Pengelolaan Lingkungan Hidup.

Undang-Undang No 32 Tahun 2009 tentang Perlindungan dan Pengelolaan Lingkungan Hidup 